\title{
ENHANCING TRACKING PRACTICES IN THE MALAYSIAN FREIGHT FORWARDING INDUSTRY
}

\author{
Zaharuzaman Jamaluddin \\ Faculty of Business and Accountancy \\ Universiti Selangor, Malaysia \\ E-mail: zaharuzaman@unisel.edu.my \\ Nor Azah Jahari \\ Faculty of Business and Accountancy \\ Universiti Selangor, Malaysia \\ E-mail: azahjahari@unisel.edu.my \\ Sharifah Hilmi Syed Abdullah \\ Faculty of Business and Accountancy \\ Universiti Selangor, Malaysia \\ E-mail: sharhilmi@unisel.edu.my \\ Norjiah Muslim \\ Faculty of Business and Accountancy \\ Universiti Selangor, Malaysia \\ E-mail: nojia@unisel.edu.my
}

\begin{abstract}
Freight forwarding is the movement of all intermodal commodities on behalf of shippers. Although the freight forwarding industry's contribution to a country's national output may not be as competitive as other sectors, the role that this industry plays in supporting an economy's activity cannot be underestimated. Furthermore, the stiff competition in the freight forwarding industry requires companies to continue to excel to survive and compete with the competitors. Thus, the purpose of this paper is to assess current literature and practices in the freight forwarding industry regarding tracking practices. Furthermore, it is expected that the documentation, freight readiness, route and technology capabilities will serve as a foundation for more effective operations and practices in Malaysia, ensuring the freight forwarding industry's sustainability. The study contributes to the body of knowledge on freight forwarding performance and can assist managers in reacting appropriately to create cost-effective logistic solutions.
\end{abstract}

Keywords: Tracking Practices, Freight Forwarding, Logistics.

\section{INTRODUCTION}

A freight forwarding company is a legal entity that is responsible for delivering freight on time while maintaining its quality and quantity in each time frame. Allowing for the signed contract of freight forwarding services, the freight forwarding company must be able to constantly track the location of cargo to ensure timely delivery of cargo and to coordinate cooperation among 
different delivery participants. However, current coordinating has identified the most common service failures in the forwarding industry from the perspective of shippers as being related to documentation such as lack of logistics planning, information, and communication such as ineffective decision-making, operation such as lack of logistic practices and error in delivering service, equipment, cost, and booking and delivery services leading to losses to both parties (Aini, Faisol, Hashim, \& Nasir, 2018; Popovych, Shyriaieva, \& Selivanova, 2016). As a result, logistics activities such as delivery planning, freight forwarding, and mode selection must be optimized. Low cost and responsiveness are critical success factors in becoming a market leader (Dua \& Sinha, 2019).

\section{Elements of Tracking Practices}

\section{LITERATURE REVIEW}

Freight forwarding providers constantly review their business strategies to provide high quality services to their customers, whose requirements are becoming more demanding in the dynamic world. Tracking practices can be defined as forwarding services which affects individual and supply chain partners that contribute to the betterment of the business performance. Hence, this paper incorporates the following elements, i.e., documentation, freight readiness, route and technology capabilities that are crucial and key practices in preserving and sustaining the performance of freight forwarding in the market as presented in Figure 1.

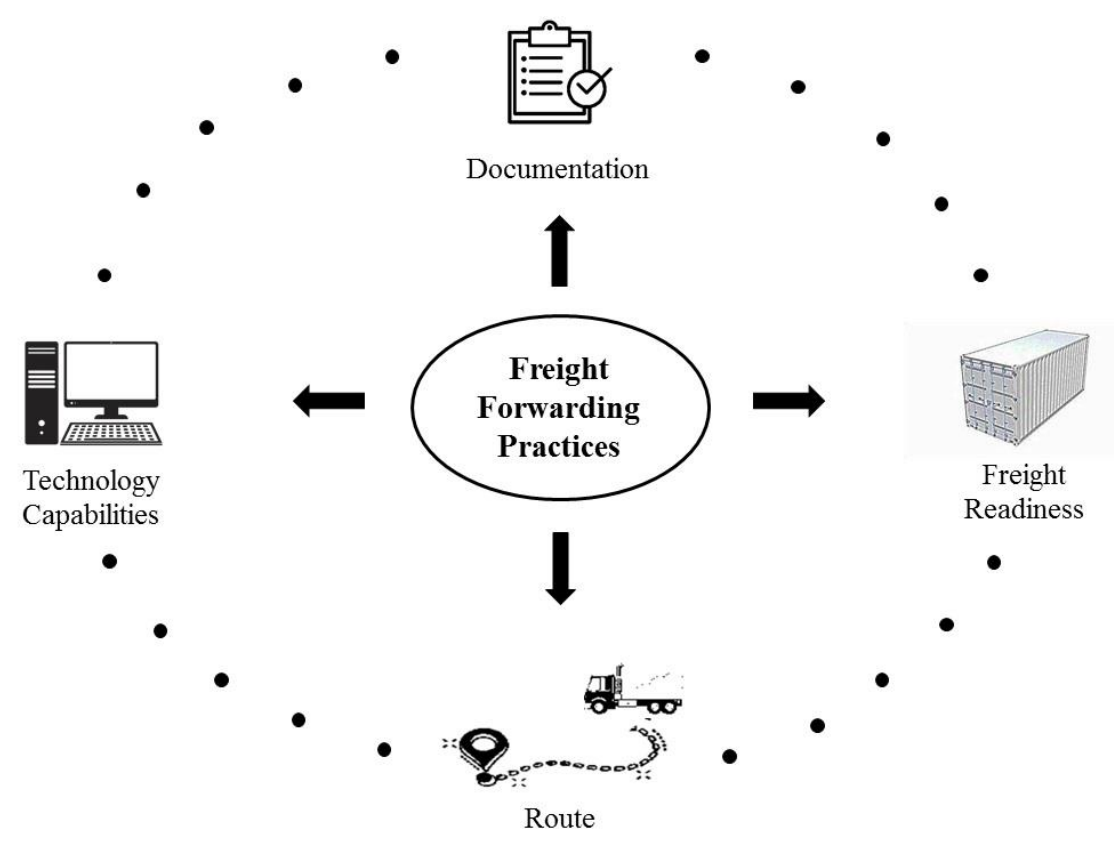

Figure 1. Freight Forwarding Practices Elements

\section{Documentation}

Documentation refers to document handling with customs officials and other authorities to transfer cargo from ports to customer (Fanam, Nguyen \& Cahoon, 2018). Depending on the type of shipment, different documentation will be required. For example, if the items being shipped 
are dangerous goods, chemical goods, water samples, or perishable items, they will almost certainly need to fill out additional documentation (C\&D Logistics, 2020). According to Mastercard Biz Caribbean (2016), documentation is one of the important elements in freight forwarding service because it shows the ownership of goods and that the items were delivered in good conditions. On the other hand, there might be an error or mistakes occurred while handling the documentation either the mistakes come from the client or the freight forwarder itself. Surely this will give a negative impact to the freight forwarder. As stated in Microdea (2018), documentation errors may cause the payment process to be slowed or even halted. Payment interruption will also affect the clients and lead them to indeterminacy of how to incorporate the fees into their broader financial plans. Next, supported by Manaadiar (2020) rerouting of cargo may happen when the freight forwarder submitted the incorrect documentation to the carrier and thus, the cargo will be ended up in another continent. If these errors happen frequently, it will result to the clients' doubtful in purchasing the service ever again.

Previous study by discovered that the most common problems are purchasing, or procurement documents and service delays caused by documentation processes (Kannikar \& Martusorn, 2019; Rabiya \& Edward, 2016). This is supported with study conducted by Nazli, Ezgi, and Durmuş (2015), where the most common service failures in the forwarding industry from the perspective of shippers are related to documentation. If freight forwarders fail to perform complex logistics activities such as documentation accurately, or if goods are not delivered on time and safely, the shipper may suffer in terms of lost sales. It is now recognized; many organizations operate their documents electronically (Martin, Pavel \& Marek, 2014).

\section{Freight Readiness}

Freight readiness refers to a specific date when the forwarding agent has the cargo ready for handover to a transportation provider (Sternberg \& Harispuru, 2016). As shared by Freightcourse (2021) it is crucial for the shippers to specify the freight readiness or cargo ready date as this allows the trucker or freight forwarder to schedule when a cargo can be picked up from the shipper's place. Due to pandemic, changes of people buying online create high demand on transportation delivery. Hence, demand for freight services exceeds supply of the readiness of the freight/cargo in delivering the product.

According to Bock (2010), changes such as traffic congestion or new transportation requests are unavoidable because they have such a large impact on the overall performance of the regulated transportation systems. Also, Alagesan and Daud (2019), by analyzing road freight transportation in various countries, it was discovered that road freight transportation has either been on the rise or is one of the most widely used modes of transportation in recent years. Also, Ghandriz, Jacobson, Laine, and Hellgren (2020) mentioned that in the near future, transportation will see significant advancement in the field of automated driving systems (ADS), which will revolutionize the way goods travel on the road. Therefore, freight readiness is important.

\section{Route}

Route means seeks to find an optimal route between two places as a standpoint of logistics companies that provide transportation service (Ohmori et al., 2017). The route is an important component in freight forwarding because it allows the freight forwarder to simulate unique static or dynamic environment requirements, as well as variables such as weather, traffic, road types, and vehicle speed (Poduch, 2017). This ensures ample, predictable supply of freight a forwarder can handle while servicing its primary customer base. 
Ohmori et al. (2017) proposed short-term subcontracting in transportation mode to reduce costs in their study on optimization problems in vehicle routing and scheduling. Aside from that, Molina et al. (2014) discovered that vehicle capacity, fuel type, and driving are the most important factors influencing the vehicle route problem. Previous study of freight trip generation (FTG) modelling on shipment sizes and number of vehicle trips using alternative distribution channels by Jaller et al. (2015) show significant differences in production and attraction patterns between establishment types, establishments across industry segments, and establishments within industries. Furthermore, Hanif and Kaluwa (2016) investigated the difficulties of freight forwarding operations. The study discovered that high transportation costs, deficiencies in road and rail infrastructure, inefficient ports, and transit border delays pose serious challenges to transportation logistics through a survey. Therefore, a strong system needs an understandable logistical border as well as appropriate transport implements and techniques to link with procedures (Kherbesh \& Mocan, 2015).

\section{Technology Capabilities}

Organizations increasingly rely on technology to improve the organization performance. becoming essential features of business strategy for the success of many leading organizations in the world. According to Closs, Goldsby and Clinton (1997) technology help in improving logistics sector competitiveness and has greatly increased in efficiency and responsiveness. For years, the freight forwarding industry as one of the industries in logistic sector has been facing high levels of global competition due to technology advancement. Technology is reshaping the logistic industry including freight forwarding, that make freight logistics even faster, cheaper, and more predictable (Gruchmann, Pratt, Eiten \& Melkonyan, 2020). Data transmission is critical, and it must be reliable and efficient. Therefore, freight forwarding companies must remain current in term of technology capabilities by applying numerous applications that will help the organization operate effectively. Furthermore, this technology capabilities have created a variety of innovative trade solutions.

Technology capabilities refers to logistics information systems that allows forwarding companies to monitor and manage logistics and supply chain networks (Ahimbisibwe et al., 2016). Empirical evidence reveals that technology capabilities is significantly correlated with organizational performance (Brah \& Lim, 2006). Organizations with high technology capabilities outperform organizations without high technology capabilities. As a result, technology capabilities are an important part of the practices in ensuring the effectiveness of all processes involved in freight forwarding along the supply chain.

\section{CONCLUSION}

This study is an early attempt to explore the important elements to enhance tracking practices in the Malaysian freight forwarding industry. Based on the literature, the key elements has been discovered are documentation, freight readiness, route and technology capabilities are interconnected with each other and each of them plays important role in the practices by the forwarding company. To facilitate the delivery of goods to customer, it is crucial to minimize the error in documentation handling and accurate route planning to ensure the freight can be delivered on time. Therefore, this paper contributes to the concept of freight forwarding operations that can be used to explain and understand the importance to improve the tracking practices. It thus, provided a base for future researchers to examine any aspects of logistics in Malaysia. 


\section{ACKNOWLEDGMENTS}

The authors gratefully acknowledged the financial support received in the form of a research grant from Universiti Selangor, I/SEM-MBI/SS/2020/02.

\section{REFERENCES}

Ahimbisibwe, A., Omudang, S., Tuiime, W., \& Tumuhairwe, R. (2016). Information technology capability, adoption, logistics service quality and the performance of third party logistics providers. European Journal of Logistics, Purchasing and Supply Chain Management, 4(2), 11-33

Aini, M. F., Faisol, N., Hashim, N., \& Nasir, S. (2018). An Overview of Construction Logistics: Main Issues and Factors That Influence Its Efficiency, Advances in Transportation and Logistics Research, 552-564

Alahgesan, S., \& Daud, D. (2019). Barriers to Implement Green Road Freight Transportation: A Case Study From Malaysia, E3S Web of Conferences - ICBTE 2019, 136, 03016

Bock, S. (2010). Real-time control of freight forwarder transportation networks by integrating multimodal transport chains, European Journal of Operational Research, 200(3), 733746

Brah, S. A., \& Lim, H. Y. (2006). The effects of technology and TQM on the performance of logistics companies. International Journal of Physical Distribution \& Logistics Management, 36(3),192-209.

Closs, D. J., Goldsby, T. J., \& Clinton, S. R. (1997). Information technology influences on world class logistics capability. International Journal of Physical Distribution \& Logistics Management. 27(1), 4-17

Dua, A., \& Sinha, D. (2019). Quality of multimodal freight transportation: a systematic literature review. World Review of Intermodal Transportation Research, 8(2), 167-194

Fanam, P.D., Nguyen, H. O., \& Cahoon, S. (2018). An empirical analysis of the critical selection criteria of liner operators: the perspective of freight forwarders. International Journal of Shipping and Transport Logistics, 10(5/6), 567-586

Ghandriz, B., Jacobson, T, Laine, L, \& Hellgren, J. (2020). Impact of automated driving systems on road freight transport and electrified propulsion of heavy vehicles, Transportation Research Part C 115 (2020) 102610

Gruchmann, T., Pratt, N., Eiten, J., \& Melkonyan, A. (2020). 4PL Digital Business Models in Sea Freight Logistics: The Case of FreightHub. Logistics, 4(2), 1-15

Hanif, R. \& Kaluwa, E. (2016). Analysis of transport logistics challenges affecting freight forwarding operations in Malawi. African Journal of Business Management, 10(24), 607-614

Importance of transport documentation in international trade. (2016). Retrieved from https://www.mastercardbiz.com/caribbean/2016/09/23/importance-of-transportdocumentation-in-international-trade/

Jaller, M., Otero-Palenciaa, C., \& Pahwaa, A. (2015) Automation, electrification, and shared mobility in urban freight: opportunities and challenges. Transportation Research Procedia, 46, 13-20

Kannikar, V., \& Martusorn, K. (2019). College Procedure Development Of Supplies Disbursement Documentation In College Of Logistics And Supply Chain,Suan Sunandha Rajaphat University

Kherbesh, O. \& Mocan, M.L. (2015). A Review of Logistics and Transport Sector as a Factor of 
Globalization. Procedia Economics and Finance, 27, 42-47

Microdea. (2018). How Documentation Mistakes Can Derail Your Shipping Service [Web log post]. Retrieved from https://www.microdea.com/document-management-blog/mobilecapture-benefits

Manaadiar, H. (2020). Risks and Liabilities of a Freight Forwarder. Shipping And Freight Resource.

Martin, H., Pavel, T., \& Marek, T. (2014). Drawing of layout documentation as the basis of logistics management system of a company literature review, new methodics, case study. International Conference on Advanced Logistics and Transport (ICALT), 356-361

Molina, J.C., Eguia, I., Racero, J., \& Guerrero, F. (2014). Multiobjective vehicle routing problem with cost and emission functions. Procedia - Social and Behavioral Sciences, $160,254-263$

Nazli, G.G.O., Ezgi, G., Durmuş, A.D. (2015). Typologies Of Freight Forwarding Service Failures And Recovery Strategies. Beykoz Akademi Dergisi, 3(2), 25-54

Ohmori, S., Yoshimoto, K., Kuriyama, S., Arunyanart, S., \& Seesonboom, W. (2017). Vehicle routing problem for freight forwarding. Asia-Pacific Journal of Science and Technology, $22(2), 1-5$

Poduch, T. (2017). Freight management and ROUTE optimization: A critical combination. Retrieved from https://www.inboundlogistics.com/cms/article/freight-management-androute-optimization-a-critical-combination/

Popovych, P., Shyriaieva, S., \& Selivanova, N. (2016). Analysis of the interaction of participants freight forwarding system. Journal of Sustainable Development of Transport and Logistics, 1(1), 16-22

Rabiya, H., \& Edward, K. (2016). Analysis of transport logistics challenges affecting freight forwarding operations in Malawi, 10(24), 607-614

Sternberg, H., \& Harispuru, L. (2016). Identifying root causes of inefficiencies in road haulage: case studies from Sweden, Switzerland and Germany. International Journal of Logistics Research and Applications, 20(1), 73-83

The Importance of Shipping Documents: C\&D Logistics. (2020). Retrieved from https://www.cdlogistics.ca/freight-news/importance-shipping-documents/

What is the meaning of cargo ready date (crd)? (2021). Retrieved from https://www.freightcourse.com/what-is-cargo-ready-date/

\section{Copyrights}

Copyright for this article is retained by the author(s), with first publication rights granted to the journal. This is an open-access article distributed under the terms and conditions of the Creative Commons Attribution license (https://creativecommons.org/licenses/by/4.0) 